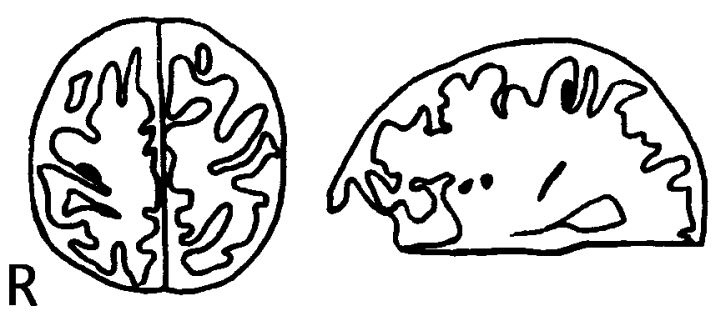

Patient 1

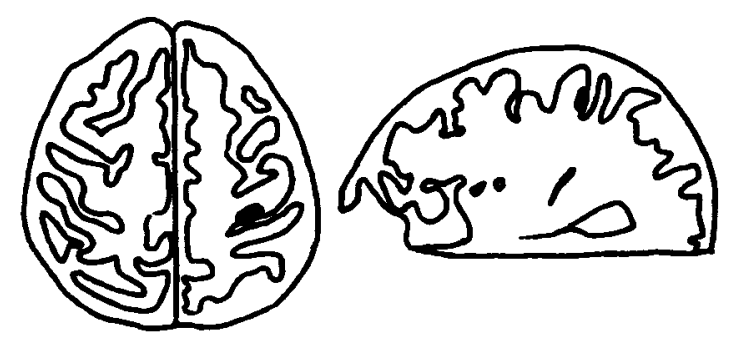

Patient 3

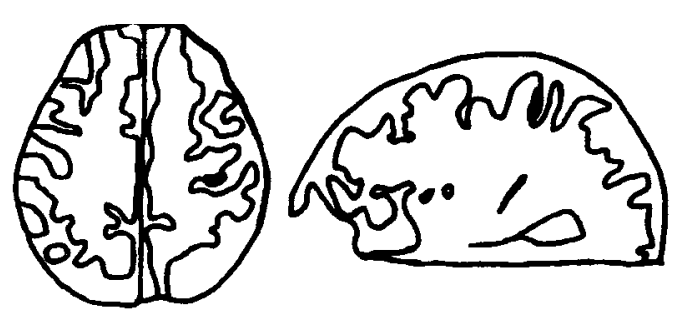

Patient 2

Figure 2. Schematic drawings of the lesions identified by MRI or CT in five patients.

7. Yoneda Y, Mori E, Tabuchi M, Yamadori A. Pure motor monoparesis due to intracerebral hemorrhage. Stroke 1993;24:142-143.

8. Hochman MS, DePrima SJ. Early diagnosis by diffusionweighted MRI of pure motor stroke limited to finger weakness. J Neuroimaging 1998;8:179-181.
9. Lee $\mathrm{PH}, \mathrm{Han} \mathrm{SW}, \mathrm{Heo} \mathrm{JH}$. Isolated weakness of the fingers in cortical infarction. Neurology 1998;50:823-824.

10. Phan TG, Evans BA, Huston J. Pseudoulnar palsy from a small infarct of the precentral knob. Neurology 2000;54:21852186.

\title{
Cheiro-oral syndrome due to a midbrain lesion
}

H. Aizawa, MD, N. Makiguchi, MD, T. Katayama, MD,

S. Koyama, MD, K. Kikuchi, MD, Asahikawa, Japan

To our knowledge, only hemorrhage and cavernous angioma have been reported as midbrain lesions causing cheiro-oral syndrome. ${ }^{1,2}$ We report a case of cheiro-oral syndrome caused by a small lesion confined to the medial lemniscus in the medbrain, probably an ischemic lacunar infarct. A 42-year-old woman noted tingling on the left side of her mouth and left hand. Neurologic examination disclosed no abnormalities except for sensory disturbance in the left hand and mouth regions. T2-weighted MRI showed highintensity lesion in the right midbrain (figure). There were no other brain lesions except for the right midbrain lesion.

1. Ono $\mathrm{S}$, Inoue K. Cheiro-oral syndrome following midbrain haemorrhage. J Neurol 1985;232:304-306.

2. Holter JT, Tijssen C. Cheiro-oral syndrome: does it have specific localizing value? Eur Neurol 1988;28:326-330.

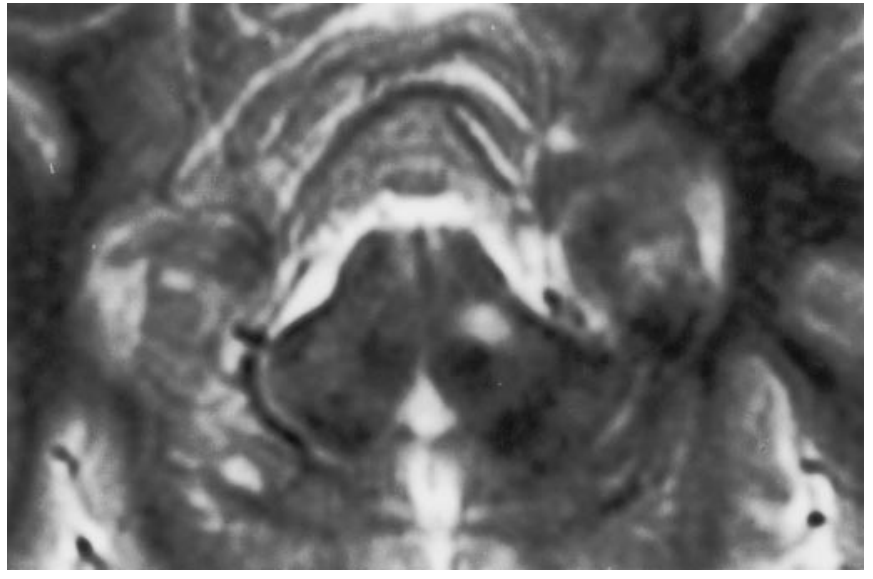

Figure. T2-weighted MRI shows a small high-intensity area in the medial lemniscus of the right midbrain. 


\section{Neurology}

\section{Cheiro-oral syndrome due to a midbrain lesion}

H. Aizawa, N. Makiguchi, T. Katayama, et al.

Neurology 2002;58;1414

DOI 10.1212/WNL.58.9.1414

\section{This information is current as of May 14, 2002}

\section{Updated Information \& Services}

\section{References}

Subspecialty Collections

Permissions \& Licensing

Reprints

\section{including high resolution figures, can be found at:} http://n.neurology.org/content/58/9/1414.full

This article cites 2 articles, 0 of which you can access for free at: http://n.neurology.org/content/58/9/1414.full\#ref-list-1

This article, along with others on similar topics, appears in the following collection(s):

\section{Infarction}

http://n.neurology.org/cgi/collection/infarction

\section{MRI}

http://n.neurology.org/cgi/collection/mri

Information about reproducing this article in parts (figures,tables) or in its entirety can be found online at:

http://www.neurology.org/about/about_the_journal\#permissions

Information about ordering reprints can be found online:

http://n.neurology.org/subscribers/advertise

Neurology ${ }^{\circledR}$ is the official journal of the American Academy of Neurology. Published continuously since 1951, it is now a weekly with 48 issues per year. Copyright . All rights reserved. Print ISSN: 0028-3878.

Online ISSN: 1526-632X.

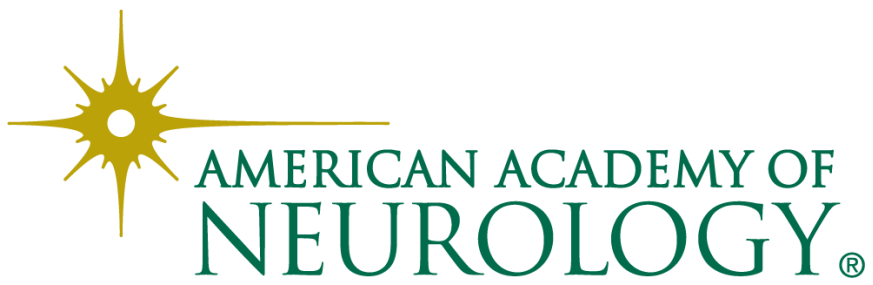

